\title{
UV Radiation Resistance-Associated Gene Protein
}

National Cancer Institute

\section{Source}

National Cancer Institute. UV Radiation Resistance-Associated Gene Protein. NCI

Thesaurus. Code C113223.

UV radiation resistance-associated gene protein (699 aa, $78 \mathrm{kDa}$ ) is encoded by the human UVRAG gene. This protein is involved in both DNA repair and the positive regulation of autophagy. 